\title{
Research and Application of Interactive Teaching Mode in Senior English Class
}

\author{
Limei Chen \\ China West Normal University, Nanchong, Sichuan, China
}

\begin{abstract}
Most high school English teaching classrooms are instilling knowledge and filling duck teaching led by teachers, ignoring the subjectivity of students. It, as a result, dampens students' enthusiasm for learning. Under the background of the new era curriculum reform concept, the classroom interactive teaching mode exerts its unique advantages, greatly mobilizes the enthusiasm of students in learning, changes the single interactive teaching mode, and enhances the interaction and communication between students and teachers. Therefore, this paper analyzes the research and application of classroom interactive teaching mode in high school English teaching.
\end{abstract}

Key words: high school English classroom; interactive teaching mode; application

\section{Introduction}

With the development of society, the quality and requirements of education are getting higher and higher, and traditional teaching models can no longer meet the requirements of social progress. From the interactive level in classroom teaching, this article studies the new interactive teaching mode in high school English classroom, its characteristics and advantages on how to play a role in high school English classroom, and how to make up for the shortcomings of the traditional teaching process.

\section{The Concept of Interactive Teaching Mode}

The application of interactive teaching mode fundamentally balances the relationship between teachers and students. In other words, the application of interactive teaching mode fundamentally changes the current status of teachers in the education system, and let teachers understand students' interests.

\section{Analysis of the Present Situation of Traditional Teaching}

3.1 The classroom is led by teachers, ignoring the subjectivity of students

The teacher controls the teaching classroom, and the teaching link is completely under the control of the teacher. Classroom teaching has a single form, with teachers mainly imparting knowledge and students receiving knowledge. Students become robots, while teachers only need to instill endless knowledge into students. The degree of students' absorption of knowledge and whether the knowledge can be applied is still inconclusive. The atmosphere of the entire classroom is dull and boring, with only a few students in the classroom actively listen to the lectures, while a large group of students in the back row are buried in sleep or keep taking notes. In the "cramming" English classroom teaching, many students rely on a large number of questions to improve their English performance. As a result, their listening and speaking skills are poor (Li Shudan, 2018). Under this circumstance, students only record the knowledge, but do not understand the

Copyright (C) 2021 by author(s) and Frontier Scientific Research Publishing Inc.

This work is licensed under the Creative Commons Attribution International License (CC BY 4.0).

http://creativecommons.org/licenses/by/4.0/ 
usage. After class, they will continue to consult the teacher, sacrifice the rest time, causing the low efficiency and learning motivation.

3.2 Students' learning efficiency is low, and their learning motivation and confidence are frustrated

Most high school English teaching classes focus on teaching new grammar, memorizing knowledge points and expanding new words, but they are not as fun as elementary and junior high schools. A lot of knowledge is boring and difficult to understand. Therefore, it is easy to cause underachievers to find their way in the classroom and fail to keep up with the teacher's learning pace. Over time, they become more and more strenuous, feel ignored by the teacher, frustrated in learning motivation, and even feel tired of learning. Therefore, facing the bitterness and difficulty of high school English knowledge, how to change the boring status quo of the traditional teaching classroom is worthy of every teacher's thinking.

3.3 The teaching method of teachers is single, and students lack motivation

High school English classrooms are generally based on teachers, while students only listening and taking notes. In the precious classroom time, students become note-taking robot. In addition, the high school grammar is complex, and the vocabulary requirements and the English ability requirements are high. As a result, the teacher can only instill the complex knowledge into the students one by one, so that they can record it in the form of excerpted notes. In this way, even if the teacher has completed the task of each lesson, the students still know nothing. Besides, the cultivation of students' own thinking ability and the ability to learn and apply knowledge is also carried out in the form of extracting notes from each class. Therefore, teachers should strive to change the traditional way of teaching and mobilize students to participate in the classroom learning and thinking instead of copying notes and study hard after class, which will eventually consume a lot of energy, dampen their self-confidence, and lead to a direct decline in the enthusiasm of students.

\section{The Application of Interactive Teaching Mode in High School English Classroom}

4.1 Create a relaxed learning atmosphere before class and adopt various teaching media to mobilize students' interest in learning

Before learning difficult or boring grammar knowledge points, teachers can use information-based teaching methods such as micro-lectures, electronic whiteboards, and interactive all-in-one machines to create rich and interesting interactive scenarios and a relaxed environment. The pleasant teaching atmosphere allows students to germinate strong curiosity, thereby inspiring their interest in learning (Wu Meng, 2016), so that underachievers are not afraid of learning, and students at all stages integrate into the new knowledge. In this way, teachers can get closer to student life and mobilize their fun. After reading or listening to the topics introduced by the teacher, students can hold group discussions or discuss with the same table, predict the knowledge points they will learn, and perceive new knowledge in advance, thereby enhancing their learning motivation. Teachers can also use their imagination and their own life experience to collide existing knowledge with other students' knowledge to stimulate their motivation for learning. It, however, should be noted that the application of teaching equipment should be appropriate, because there are also drawbacks. For example, excessive use will cause students to be distracted and focus their attention on areas that are not related to the classroom. Therefore, teachers should grasp this degree well.

4.2 Students are the main body in the class, and various forms such as question and answer are used to mobilize students' learning enthusiasm

Question interaction is one of the most commonly used methods in the task teaching method, which is manifested by teachers by asking some enlightening or task-based questions to stimulate students' enthusiasm for interaction and exercise their thinking ability (Zhou Liying, 2012). After introducing the more difficult knowledge points, the teacher should let the students understand the reason for each knowledge point and how to apply the knowledge point. Therefore, the valuable 
classroom time should be used to conduct questions and answers or other forms of interactive links to consolidation. For example, the teacher can conduct random questions. It can be random questions from individual students, the whole class, or the teacher divides all the students into several groups for a few minutes to discuss, and then applies the knowledge points. Second, the teacher grades, and controls the time within a reasonable range to increase the interactivity of students. Finally, the teacher selects the best group to show the results in the whole class. Therefore, teachers should add some interactive links as much as possible when designing teaching links so that all students in the class can participate, and encourage stamina students to participate in the classroom, which will make the learning atmosphere stronger.

4.3 Let students conduct group cooperation and role play after class to consolidate and deepen new knowledge

After learning new grammar knowledge points or a text, teachers can design links to consolidate or expand knowledge, so that students can complete them in class. Students' homework includes not only written assignments, but also practical homework and topics. Students discuss with classmates or perform role-plays after class, which not only consolidates the new knowledge, but also paves the way for the review and consolidation of the next class, and avoids students' resistance to a single heavy assignment.

\section{The Significance and Role of Interactive Teaching Mode in High school English Classroom}

\section{Teaching}

5.1 Change the boring classroom atmosphere and make students more interested in English

The interactive teaching model can make students more interested in English learning and feel that English learning is easier. Students will not be afraid of learning English, and are more willing to communicate with teachers in class, even ask questions about the knowledge presented by teachers. The initiative of students is obviously strengthened, and the classroom atmosphere is more lively and vivid instead of being dull as serious as before. Students are more enthusiastic about English knowledge, and will consciously think and explore the teacher's questions.

5.2 Improve students' thinking ability and cultivate their teamwork and expression skills

Through various forms of interaction, whether it is the interaction between teachers and one student, teachers and all students, or students and students, students are communicating and discussing knowledge with another individual. Therefore, they need to give play to their thinking skills and use the knowledge they have learned to analyze and solve problems. This has unintentionally cultivated their ability to think about problems, which will be of great benefit in future study and life, and strengthen the communication and expression skills of students in group cooperation or peer exchanges. This spark of knowledge is collided, which improves students' expression ability and teamwork ability in a subtle way, and it is extremely important to deal with personnel relations in future work.

5.3 Change the traditional teaching mode and promote the common development of teachers and students

In the past, the teaching form was single, students could not improve their comprehensive qualities, and teachers did not reflect on themselves in the classroom, leading to stagnant teaching. So teachers permeate interaction into the classroom, and designing some interactive links is undoubtedly a big step for teachers' growth. Teachers need to continuously reflect and correct problems in teaching in a timely manner. The interactive mode can also reflect that teachers are changing traditional teaching concepts, accepting new teaching concepts, and continuously promoting their self-growth. At the same time, the increasing the interaction between teachers and students, students and students will undoubtedly make students more aware of the teacher's attention to them without being ignored, and also allow teachers to better understand the needs of students and solve their problems in a timely manner. This kind of interaction is also an important feedback about the learning students' situation. Finally, mutual understanding between students and teachers will promote the harmonious relationship and the formation of a good teacher-student relationship, laying a solid emotional 
foundation for students' learning. Only when students truly like the teacher can they have a strong interest in learning.

\section{Conclusions}

Based on the above, the traditional teaching model has been unable to adapt to my country's concept of comprehensive development of talent training, and the interactive teaching model has brought vitality to the high school English classroom. In this mode, students are more proactively integrated into the classroom, becoming the protagonist of this stage, and their initiative is reflected. In addition, the interactive teaching mode will give students a better understanding between teachers and students, the teacher-student relationship will be more harmonious, and the students will be more energetic.

\section{Conflicts of Interest}

The author declares no conflicts of interest regarding the publication of this paper.

\section{References}

[1] Li S.D. (2018). Research on the Construction and Application of Interactive Teaching Mode in Junior Middle School English Teaching. English Square, (10): 160-161.

[2] Wu M. (2016). An Empirical Study of Interactive Teaching Mode in Junior Middle School English Reading Teaching. Harbin Normal University, Harbin.

[3] Zhou L.Y. (2012). The Application and Research of Interactive Cooperative Teaching Model in Junior Middle School English Teaching. Central China Normal University, Wuhan.

[4] Rivers W. M. (1987). Interactive Language Teaching.Cambridge University Press, Cambridge. 